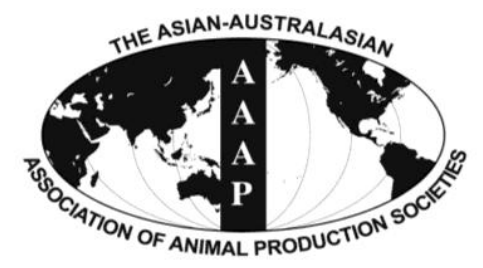

Asian-Aust. J. Anim. Sci.

Vol. 25, No. 2 : 267 - 271

February 2012

www.ajas.info

http://dx.doi.org/10.5713/ajas.2011.11320

\title{
One Alpha-hydroxycholecalciferol Improves Growth Performance, Tibia Quality, and Meat Color of Broilers Fed Calcium- and Phosphorus-Deficient Diets
}

\author{
J. C. Han, Y. L. Wang, H. X. Qu, F. Liang, J. L. Zhang, C. X. Shi, X. L. Zhang, L. Li, Q. Xie, \\ C. L. Wang, Y. Y. Yan, X. S. Dong ${ }^{1}$ and Y. H. Cheng* \\ College of Life Science, Shangqiu Normal University, Shangqiu, Henan, 476000, China
}

\begin{abstract}
An experiment was conducted to evaluate the effects of one alpha-hydroxycholecalciferol $\left(1 \alpha-\mathrm{OH} \mathrm{D}_{3}\right)$ on growth performance, tibia quality, and skin and meat color in broilers fed calcium (Ca)- and phosphorus (P)-deficient corn-soybean meal diets. A total of 288 male Ross broilers, at 21 days of age, were randomly assigned to three treatments with eight cages per treatment. Three levels of $1 \alpha-\mathrm{OH} \mathrm{D}_{3}(0,5$, and $10 \mu \mathrm{g} / \mathrm{kg})$ were added to a basal diet $(0.50 \% \mathrm{Ca}, 0.13 \%$ non-phytate phosphorus (NPP), and $0.35 \%$ total phosphorus (tP)) without vitamin $\mathrm{D}_{3}$. As a result of this study, the addition of $1 \alpha-\mathrm{OH} \mathrm{D}_{3}$ increased body weight gain $(\mathrm{p}<0.001)$, feed intake $(p=0.007)$, feed efficiency $(p<0.001)$, tibia weight $(p=0.002)$, length $(p<0.001)$, breaking-strength $(p=0.012)$, ash $(p<0.001)$, $\mathrm{Ca}(\mathrm{p}<0.001)$, and $\mathrm{P}$ content $(\mathrm{p}=0.004)$. Dietary $1 \alpha-\mathrm{OH} \mathrm{D}_{3}$ enhanced breast meat yellowness $(\mathrm{p}=0.015)$ and the length and weight of the small intestine of the broilers. Moreover, $1 \alpha-\mathrm{OH} \mathrm{D}_{3}$ decreased serum Ca concentration $(\mathrm{p}=0.074)$ and breast meat redness $(\mathrm{p}=$ 0.010). These results indicate that the $1 \alpha-\mathrm{OH} \mathrm{D}_{3}$ improves growth, tibia quality, and meat color in broilers fed Ca- and P-deficient cornsoybean meal diets. (Key Words : One Alpha-hydroxycholecalciferol, Growth Performance, Tibia Quality, Meat Color, Broiler)
\end{abstract}

\section{INTRODUCTION}

As an analog of cholecalciferol (vitamin $\mathrm{D}_{3}$ ), the one alpha-hydroxycholecalciferol $\left(1 \alpha-\mathrm{OH} \mathrm{D}_{3}\right)$ is slightly lower in efficacy than 1,25-dihydroxycholecalciferol $\left(1,25-(\mathrm{OH})_{2} \mathrm{D}_{3}\right)$ in broilers (Edwards, 2002). Biehl and Baker (1997b) and Snow et al. (2004) reported that $1 \alpha-\mathrm{OH} \mathrm{D}_{3}$ improves growth performance, tibia quality, and phosphorus $(\mathrm{P})$ utilization in broilers. However, most studies focus only on starter broilers, and to date, limited information is available on growing-finishing phase birds.

Previous studies on $1 \alpha-\mathrm{OH} \mathrm{D}_{3}$ have been based on adequate dietary vitamin $\mathrm{D}_{3}$ (Biehl and Baker, 1997a, 1997b; Snow et al., 2004; Driver et al., 2005). Edwards (2002) found that an interaction between vitamin $D_{3}$ and

\footnotetext{
* Corresponding Author : Y. H. Cheng. College of Bioresources, Department of Animal Science, I-Lan University, I-Lan, Taiwan, 26047, ROC. Tel: +886-39317712, Fax: +886-39359005, E-mail: yhcheng@niu.edu.tw

1 Taizhou Healtech Chemical Co., Ltd., Taizhou, Zhejiang, 318000, China.
}

Received September 7, 2011; Accepted November 2, 2011
1,25- $(\mathrm{OH})_{2} \quad \mathrm{D}_{3}$ exists in tibia ash. To avoid possible interactions between vitamin $\mathrm{D}_{3}$ and $1 \alpha-\mathrm{OH} \mathrm{D}_{3}$, we investigate the effect of $1 \alpha-\mathrm{OH} \mathrm{D}_{3}$ in a basal diet without vitamin $\mathrm{D}_{3}$. Our unpublished data showed that $1 \alpha-\mathrm{OH} \mathrm{D}_{3}$ efficacy responds negatively to increasing dietary calcium (Ca) levels, and $1 \alpha-\mathrm{OH} \mathrm{D}_{3}$ yields the highest activities at low concentrations of dietary Ca (Han et al., 2012). Therefore, in the present experiment, a low-Ca diet was designed.

Broiler skin and meat color is important sensory characteristics by which consumers judge meat quality (Petracci and Fletcher, 2002). In our published work, Han et al. (2009) found that $1 \alpha-\mathrm{OH} \mathrm{D}_{3}$ enhances the lightness and yellowness of breast and thigh meat of 1- to 21-d-old broilers. Previous studies on swine showed that the lightness of pork decreases and the redness increases or is not affected, by the addition of vitamin $\mathrm{D}_{3}$ (Wiegand et al., 2002; Wilborn et al., 2004). However, the effects of $1 \alpha-\mathrm{OH}$ $\mathrm{D}_{3}$ on skin color in broilers have not been examined. Petracci and Fletcher (2002) reported that broiler skin and meat color dramatically changes during the first $6 \mathrm{~h}$ postmortem. Thus, broiler skin and meat color were 
determined immediately after the broilers were slaughtered.

The effect of $1 \alpha-\mathrm{OH} \mathrm{D}$ on weight and length of small intestine remains unclear. Therefore, the objective of the current experiment is to evaluate the effects of $1 \alpha-\mathrm{OH} \mathrm{D}$ on growth performance, tibia quality, skin and meat color, as well as small intestine parameters in broilers fed $\mathrm{Ca}$ - and P-deficient diets.

\section{MATERIALS AND METHODS}

\section{Birds, diets, and management}

All procedures in the present experiment were approved by the Animal Care Committee of Shangqiu Normal University.

On the day of hatch, 288 male Ross broiler chicks were randomly and equally assigned to 24 cages $(70 \times 70 \times 30 \mathrm{~cm})$, with 12 chicks per cage. All chicks were fed a starter mash feed (apparent metabolizable energy (AME), 2,940 kcal/kg; crude protein (CP), 20\%; Ca, 1\%; total phosphorus (tP), $0.68 \%$; non-phytate phosphorus (NPP), $0.45 \%$ ) until they were three weeks old. On d 21, the broilers were individually weighed, transferred to growing-finishing cages $(200 \times 50 \times 35 \mathrm{~cm})$, and then assigned to one of the three dietary treatments with eight replicates per treatment. Three levels of $1 \alpha-\mathrm{OH} \mathrm{D} \mathrm{D}_{3}(0,5$, and $10 \mu \mathrm{g} / \mathrm{kg})$ were added to a basal diet $(0.50 \% \mathrm{Ca}, 0.13 \% \mathrm{NPP}, 0.35 \% \mathrm{tP})$ without vitamin $\mathrm{D}_{3}$ (Table 1$)$. The crystalline $1 \alpha-\mathrm{OH} \mathrm{D}_{3}$, supplied by Taizhou Healtech Chemical Co., Ltd. (Taizhou, China), was dissolved in ethanol, and then brought to a final concentration of $10 \mathrm{mg} / \mathrm{L}$ of $1 \alpha-\mathrm{OH} \mathrm{D}_{3}$ in a solution of $5 \%$ ethanol and 95\% propylene glycol (Biehl and Baker, 1997b).

The birds were given access to mash feed and water $a d$ libitum during the 21-d experiment, with an 18-h lighting schedule.

\section{Collection and analysis of samples}

To collect blood and tibias, two chicks were randomly selected from each replicate and weighed (Edwards, 2002). Blood samples $(5 \mathrm{ml})$ were collected into 5-ml anticoagulated syringes (Shanghai K\&G International Co. Ltd., Shanghai, China) through the wing vein, and then centrifuged for $10 \mathrm{~min}$ at $3,000 \mathrm{~g}$ at $20^{\circ} \mathrm{C}$. The birds were sacrificed by exsanguination. Serum $\mathrm{Ca}$ and inorganic phosphate $(\mathrm{Pi})$ were determined with a Shimadzu CL-8000 Analyzer (Shimadzu Corp., Kyoto, Japan) following the manufacturer's instructions.

The left and right tibias of the individual birds were excised. According to the method by Hall et al. (2003), the left tibias were boiled for 5 min to loosen the muscle tissues. The meat, connective tissue, and the fibula bone were then removed completely using scissors and forceps. After the tibias were cleaned, they were put into a container with ethanol for $48 \mathrm{~h}$ (removing water and polar lipids). The
Table 1. Ingredients and nutrient composition of the basal diet

\begin{tabular}{lc}
\hline Ingredient (\%) & Basal diet \\
\hline Corn & 68.74 \\
Soybean meal & 26.46 \\
Soybean oil & 0.60 \\
Swine lard & 0.39 \\
Corn gluten meal & 1.80 \\
Limestone & 1.14 \\
L-lysine.HCl & 0.18 \\
DL-methionine & 0.06 \\
Trace mineral premix & \\
Vitamin premix & \\
Choline chloride & 0.10 \\
Sodium chloride & 0.03 \\
Nutrient composition & 0.20 \\
$\quad$ Metabolizable energy $(\mathrm{MJ} / \mathrm{kg})$ & 0.30 \\
Calculated CP $(\%)$ & \\
Analyzed CP $(\%)$ & 12.51 \\
Calculated Ca (\%) & 18.50 \\
Analyzed Ca (\%) & 18.90 \\
Calculated total P $(\%)$ & 0.50 \\
Analyzed total P $(\%)$ & 0.67 \\
Calculated non-phytate P $(\%)$ & 0.35 \\
\hline
\end{tabular}

${ }^{1}$ The trace mineral premix provided (per $\mathrm{kg}$ of diet): iron, $100 \mathrm{mg}$; zinc, $100 \mathrm{mg}$; copper, $8 \mathrm{mg}$; manganese, $120 \mathrm{mg}$; iodine, $0.7 \mathrm{mg}$; and selenium, $0.3 \mathrm{mg}$.

${ }^{2}$ The vitamin premix provided (per kg of diet): vitamin A, 8,000 IU; vitamin E, $20 \mathrm{IU}$; menadione, $0.5 \mathrm{mg}$; thiamine, $2.0 \mathrm{mg}$; riboflavin, 8.0 $\mathrm{mg}$; niacin, $35 \mathrm{mg}$; pyridoxine, $3.5 \mathrm{mg}$; vitamin $\mathrm{B}_{12}, 0.01 \mathrm{mg}$; pantothenic acid, $10.0 \mathrm{mg}$; folic acid, $0.55 \mathrm{mg}$; and biotin, $0.18 \mathrm{mg}$.

bones were further extracted in anhydrous ether for $24 \mathrm{~h}$ (removing non-polar lipids). The tibias were dried at $105^{\circ} \mathrm{C}$ for $24 \mathrm{~h}$, and then weighed. The tibia diameter was determined at the medial point, and the tibia ash content was determined by ashing the bone in a muffle furnace for $18 \mathrm{~h}$ at $600^{\circ} \mathrm{C}$ (Han et al., 2009). Skin color values of lightness $\left(\mathrm{L}^{*}\right)$, redness $\left(\mathrm{a}^{*}\right)$, and yellowness $\left(\mathrm{b}^{*}\right)$ were determined on the area between the pectoral and sternal feather tracts and the meat colors measured on the raw muscles (Petracci and Fletcher, 2002). Color values of skin and meat were measured by a Chroma Meter WSC-S (Shanghai Precision and Scientific Instrument Co., Ltd., Shanghai, China).

The right tibia was used to analyze the breakingstrength. Tibia breaking-strength was determined using an all-digital electronic universal testing machine (Shenzhen Hengen Instrument Co. Ltd., Shenzhen, China). The tibias were cradled on two support points $4 \mathrm{~cm}$ apart. By using a $50-\mathrm{kg}$ load cell and a crosshead speed of $10 \mathrm{~mm} / \mathrm{min}$, force was applied to the midpoint of the same facial of each tibia (Jendral et al., 2008). 
The whole small intestine was isolated immediately from the gastrointestinal tract and cut into 3 pieces: duodenum, jejunum, and ileum. The weight and length of the three intestinal pieces were measured (Wang and Peng, 2008).

\section{Statistical analysis}

The replicate means served as the experimental unit for statistical analysis. All data were analyzed using the ANOVA procedure of SAS software (SAS Institute, 2001) as factorial experiments, with all statements of significance $\mathrm{p} \leq 0.05$ unless indicated otherwise.

\section{RESULTS AND DISCUSSION}

\section{Growth performance and tibia quality}

The diet consisting of $0.50 \% \mathrm{Ca}$ and $0.13 \% \mathrm{NPP}$ resulted in severe deficiencies of $\mathrm{Ca}$ and $\mathrm{P}$ in the broilers. The body weight gain (BWG) in birds fed basal diets was only $467 \mathrm{~g}$ (Table 2). The addition of 5 and $10 \mu \mathrm{g} / \mathrm{kg}$ of $1 \alpha-\mathrm{OH} \mathrm{D}_{3}$ corrected the $\mathrm{Ca}$ and $\mathrm{P}$ deficiency and increased the BWG to 745 and $949 \mathrm{~g}$, respectively. Dietary $1 \alpha-\mathrm{OH} \mathrm{D}_{3}$ also improved feed intake (FI, $\mathrm{p}=0.007)$, feed efficiency (FE, $\mathrm{p}<0.001)$, tibia weight $(\mathrm{p}=0.002)$, length $(\mathrm{p}<0.001)$, breaking-strength $(\mathrm{p}=0.012)$, ash $(\mathrm{p}<0.001), \mathrm{Ca}(\mathrm{p}<0.001)$, and $\mathrm{P}$ content $(\mathrm{p}=0.004)$. However, $1 \alpha-\mathrm{OH} \mathrm{D}_{3}$ did not significantly increase serum $\mathrm{Pi}(\mathrm{p}=0.261)$ or decreased the serum Ca concentration ( $\mathrm{p}=0.074)$.

Research has shown that sodium-dependent phosphate absorption by intestinal brush-border membrane vesicles (BBMV) decreases with age in rats; NaPi-IIb gene expression also decreases proportionally with age (Xu et al., 2002). The compound $1 \alpha-\mathrm{OH} \mathrm{D}_{3}$ is metabolized to $1,25-(\mathrm{OH})_{2} \mathrm{D}_{3}$ in the intestines of chicks (Edelstein et al., 1978). Dietary 1,25-(OH $)_{2} \quad \mathrm{D}_{3}$ increases phosphate absorption in suckling and adult rats and enhances $\mathrm{NaPi}-\mathrm{IIb}$ mRNA abundance in suckling rats (Xu et al., 2002). However, 1,25- $(\mathrm{OH})_{2} \mathrm{D}_{3}$ has no effect on NaPi-IIb mRNA in adults (Xu et al., 2002). These results indicate that the efficacy of vitamin $\mathrm{D}$ analogue on $\mathrm{P}$ metabolism is influenced by animal age.

Previous studies on $1 \alpha-\mathrm{OH} \mathrm{D}_{3}$ have been based on starter broilers, in which $1 \alpha-\mathrm{OH} \mathrm{D}_{3}$ improves growth performance, tibia ash, and $\mathrm{P}$ retention (Biehl and Baker, 1997b; Edwards, 2002). In the present study, the addition of $1 \alpha-\mathrm{OH} \mathrm{D}_{3}$ increased $\mathrm{BWG}, \mathrm{FI}$, and $\mathrm{FE}$ in $\mathrm{Ca}-$ and $\mathrm{P}-$ deficient diets of 21- to 42-d-old broilers, which agreed with the results of 1- to 21-d-old broilers reported by Snow et al. (2004). Tibia quality was also enhanced by the addition of $1 \alpha-\mathrm{OH} \mathrm{D}_{3}$. The tibia weight and breakingstrength improvement by $1 \alpha-\mathrm{OH} \mathrm{D}_{3}$ came from the increase in tibia $\mathrm{Ca}$ and $\mathrm{P}$. Dietary $1 \alpha-\mathrm{OH} \mathrm{D}_{3}$ decreased serum $\mathrm{Ca}$ concentration $(\mathrm{p}=0.074)$, which agreed with the previous research on starters by Edwards (2002) and Han et al. (2009). The addition of $1 \alpha-\mathrm{OH} \mathrm{D}_{3}$ showed a trend of increasing serum Pi concentration, but the difference was not significant.

Table 2. Effect of $1 \alpha$-OH $D_{3}$ on growth performance, serum minerals, and tibia qualities of 21 - to 42 -d-old broilers ${ }^{1}$

\begin{tabular}{|c|c|c|c|c|c|}
\hline \multirow{2}{*}{ Item $^{2}$} & \multicolumn{3}{|c|}{$1 \alpha-\mathrm{OH} \mathrm{D} 3(\mu \mathrm{g} / \mathrm{kg})$} & \multirow{2}{*}{$\mathrm{SEM}^{3}$} & \multirow{2}{*}{$\mathrm{p}$ value } \\
\hline & 0 & 5 & 10 & & \\
\hline \multicolumn{6}{|l|}{ Growth } \\
\hline BWG (g) & $467^{\mathrm{c}}$ & $745^{b}$ & $949^{\mathrm{a}}$ & 46 & $<0.001$ \\
\hline FI $(g)$ & $1,590^{\mathrm{b}}$ & $1,818^{a b}$ & $2,092^{\mathrm{a}}$ & 70 & 0.007 \\
\hline $\mathrm{FE}(\mathrm{BWG} / \mathrm{FI})$ & $0.29^{b}$ & $0.41^{\mathrm{a}}$ & $0.45^{\mathrm{a}}$ & 0.02 & $<0.001$ \\
\hline \multicolumn{6}{|l|}{ Serum } \\
\hline $\mathrm{Ca}(\mathrm{mg} / 100 \mathrm{ml})$ & $11.59^{\mathrm{a}}$ & $10.32^{\mathrm{ab}}$ & $8.87^{\mathrm{b}}$ & 0.49 & 0.074 \\
\hline Pi (mg/100 ml) & 2.24 & 2.58 & 2.98 & 0.17 & 0.261 \\
\hline \multicolumn{6}{|l|}{ Tibia } \\
\hline Weight (g) & $2.66^{\mathrm{b}}$ & $2.93^{b}$ & $3.45^{\mathrm{a}}$ & 0.10 & 0.002 \\
\hline Length $(\mathrm{cm})$ & $6.52^{c}$ & $7.24^{b}$ & $7.78^{\mathrm{a}}$ & 0.12 & $<0.001$ \\
\hline Width (cm) & 0.74 & 0.68 & 0.74 & 0.02 & 0.210 \\
\hline Breaking-strength $(\mathrm{N})$ & $79.87^{\mathrm{b}}$ & $71.10^{\mathrm{b}}$ & $107.40^{\mathrm{a}}$ & 5.49 & 0.012 \\
\hline $\operatorname{Ash}(\%)$ & $32.61^{b}$ & $37.74^{\mathrm{a}}$ & $38.93^{\mathrm{a}}$ & 0.74 & $<0.001$ \\
\hline $\mathrm{Ca}(\%)$ & $12.12^{\mathrm{b}}$ & $14.10^{\mathrm{a}}$ & $14.49^{\mathrm{a}}$ & 0.27 & $<0.001$ \\
\hline $\mathrm{P}(\%)$ & $5.53^{\mathrm{b}}$ & $6.49^{\mathrm{a}}$ & $6.77^{\mathrm{a}}$ & 0.17 & 0.004 \\
\hline
\end{tabular}

${ }^{1}$ Data are means of 8 replicate cages consisting of 12 birds per replicate cage.

${ }^{2} \mathrm{BWG}=$ Body weight gain, $\mathrm{FI}=$ Feed intake, $\mathrm{FE}=$ Feed efficiency, $\mathrm{Ca}=\mathrm{Calcium}, \mathrm{Pi}=$ Inorganic phosphate, $\mathrm{P}=\mathrm{Phosphorus}$

${ }^{3} \mathrm{SEM}=$ Pooled standard error of the mean. 
Table 3. Effect of $1 \alpha-\mathrm{OH} \mathrm{D}_{3}$ on skin, breast meat, and thigh meat color of 21- to 42-d-old broilers ${ }^{1}$

\begin{tabular}{lccccc}
\hline \multirow{2}{*}{ Item } & \multicolumn{3}{c}{$1 \alpha-\mathrm{OH} \mathrm{D}_{3}(\mu \mathrm{g} / \mathrm{kg})$} & \multirow{2}{*}{ SEM $^{2}$} & $\mathrm{p}$ value \\
\cline { 2 - 6 } & 0 & 5 & 10 & & \\
\hline Skin & & & & & \\
$\quad$ Lightness (L*) & 55.45 & 55.45 & 55.36 & 0.55 & 0.997 \\
Redness (a*) & 10.65 & 9.47 & 9.21 & 0.43 & 0.369 \\
$\quad$ Yellowness (b*) & 23.11 & 21.56 & 21.32 & 0.60 & 0.437 \\
Breast meat & & & & & \\
$\quad$ Lightness (L*) & 47.34 & 47.30 & 47.75 & 0.46 & 0.914 \\
Redness (a*) & $10.65^{\mathrm{a}}$ & $10.74^{\mathrm{a}}$ & $8.59^{\mathrm{b}}$ & 0.35 & 0.010 \\
$\quad$ Yellowness (b*) & $18.74^{\mathrm{b}}$ & $19.73^{\mathrm{b}}$ & $21.62^{\mathrm{a}}$ & 0.43 & 0.015 \\
Thigh meat & & & & & \\
$\quad$ Lightness (L*) & 47.81 & 47.38 & 49.51 & 0.61 & 0.336 \\
Redness (a*) & $10.30^{\mathrm{ab}}$ & $11.52^{\mathrm{a}}$ & $8.69^{\mathrm{b}}$ & 0.45 & 0.027 \\
$\quad$ Yellowness (b*) & 10.37 & 12.39 & 11.57 & 0.60 & 0.401 \\
\hline
\end{tabular}

${ }^{1}$ Data are means of 8 replicates consisting of 2 birds per replicate.

${ }^{2} \mathrm{SEM}=$ Pooled standard error of the mean

\section{Skin and meat color}

The addition of $1 \alpha-\mathrm{OH} \mathrm{D}_{3}$ did not influence the skin color of 21- to 42-d-old broilers (Table 3), but increased breast meat yellowness ( $b$ value, $p=0.015$ ) and decreased its redness (a value, $\mathrm{p}=0.010$ ). The thigh meat redness in $10 \mu \mathrm{g} / \mathrm{kg}$ of the $1 \alpha-\mathrm{OH} \mathrm{D}_{3}$ group was lower than that of the $5 \mu \mathrm{g} / \mathrm{kg}$ of $1 \alpha-\mathrm{OH} \mathrm{D} \mathrm{D}_{3}$ group $(\mathrm{p}=0.027)$.

Previous studies have shown that vitamin $\mathrm{D}_{3}$ improves the lightness and redness of pork (Wiegand et al., 2002; Wilborn et al., 2004), while $1 \alpha-\mathrm{OH} \mathrm{D}_{3}$ increases the lightness and yellowness of the breast and thigh meat of starter broilers (Han et al., 2009). In the current study, $1 \alpha-\mathrm{OH} \mathrm{D}_{3}$ enhanced breast meat yellowness and decreased its redness. Meat color is affected by $\mathrm{pH}$ and myoglobin. The $\mathrm{pH}$ value of breast meat or thigh meat is related positively to redness, but negatively to lightness and yellowness (Allen et al., 1998; Fletcher, 1999; Fletcher et al., 2000; Qiao et al., 2002). A low pH reduces the importance of myoglobin in selectively absorbing green light, resulting in meat that appears less red and more yellow (Castellini et al., 2002).

\section{Small intestine features}

The addition of $1 \alpha-\mathrm{OH} \mathrm{D}_{3}$ increased the length $(\mathrm{p}=$ $0.027, \mathrm{p}=0.010, \mathrm{p}=0.009, \mathrm{p}=0.001)$ and weight $(\mathrm{p}<$ $0.001, \mathrm{p}<0.001, \mathrm{p}<0.001, \mathrm{p}<0.001)$ of the duodenum, jejunum, ileum, and the whole small intestine, respectively.

Fassbinder-Orth and Karasov (2006) have found that feed restriction don't significantly influence the small intestine weight in the Leghorn cockerel chicks. Thus, the small intestine weight and length in boilers fed basal diets were lower significantly than those of birds fed diets with $1 \alpha-\mathrm{OH} \mathrm{D}_{3}$, which had nothing to do with feed intake in our
Table 4. Effect of $1 \alpha-\mathrm{OH} \mathrm{D}$ on small intestine length and weight of 21 - to 42 -d-old broilers ${ }^{1}$

\begin{tabular}{lrrrrr}
\hline \multirow{2}{*}{ Item } & \multicolumn{3}{c}{$1 \alpha-\mathrm{OH} \mathrm{D}_{3}(\mu \mathrm{g} / \mathrm{kg})$} & \multirow{2}{*}{ SEM $^{2}$} & $\mathrm{p}$ v value \\
\cline { 2 - 5 } & \multicolumn{1}{c}{0} & \multicolumn{1}{c}{5} & 10 & & \\
\hline Duodenum & & & & & \\
$\quad$ Length (cm) & $27.56^{\mathrm{b}}$ & $30.78^{\mathrm{a}}$ & $30.69^{\mathrm{a}}$ & 0.58 & 0.027 \\
$\quad$ Weight (g) & $8.25^{\mathrm{b}}$ & $11.36^{\mathrm{a}}$ & $12.55^{\mathrm{a}}$ & 0.54 & $<0.001$ \\
Jejunum & & & & & \\
$\quad$ Length (cm) & $47.30^{\mathrm{b}}$ & $54.93^{\mathrm{ab}}$ & $59.84^{\mathrm{a}}$ & 1.85 & 0.010 \\
$\quad$ Weight (g) & $11.91^{\mathrm{c}}$ & $16.16^{\mathrm{b}}$ & $21.96^{\mathrm{a}}$ & 1.09 & $<0.001$ \\
Ileum & & & & & \\
$\quad$ Length (cm) & $45.04^{\mathrm{b}}$ & $53.50^{\mathrm{ab}}$ & $60.74^{\mathrm{a}}$ & 2.21 & 0.009 \\
$\quad$ Weight (g) & $8.45^{\mathrm{b}}$ & $16.01^{\mathrm{a}}$ & $18.91^{\mathrm{a}}$ & 1.11 & $<0.001$ \\
Small intestine & & & & & \\
$\quad$ Length (cm) & $119.90^{\mathrm{b}}$ & $139.21^{\mathrm{a}}$ & $151.27^{\mathrm{a}}$ & 3.95 & 0.001 \\
$\quad$ Weight (g) & $28.61^{\mathrm{c}}$ & $43.53^{\mathrm{b}}$ & $53.42^{\mathrm{a}}$ & 2.41 & $<0.001$ \\
\hline
\end{tabular}

${ }^{1}$ Data are means of 8 replicates consisting of 2 birds per replicate.

${ }^{2} \mathrm{SEM}=$ Pooled standard error of the mean.

experiment. Previous research has shown that the addition of vitamin $D_{2}$ or $D_{3}$ results in longer and thinner villi and higher duodenal mucosa weights in rats (Urban and Schedl, 1969; Sampson and Krawitt, 1976). Peebles et al. (2011) reported that percentage of duodenum weight in birds fed $1.5 \%$ poultry fat with phytase and $25-\mathrm{OH} \mathrm{D}_{3}$ was greater than that of birds fed $0.75 \%$ poultry fat. In the present study, $1 \alpha-\mathrm{OH} \mathrm{D}_{3}$ increased the small intestine weight and length of broilers fed with $\mathrm{Ca}$ - and P-deficient diets. These data suggest that vitamin $\mathrm{D}_{3}$ and its metabolites can stimulate intestine development.

In conclusion, by increasing feed intake, improving feed efficiency, stimulating small intestine development, and facilitating $\mathrm{Ca}$ and $\mathrm{P}$ retention in bones, $1 \alpha-\mathrm{OH} \mathrm{D}_{3}$ improves growth, tibia quality, and meat color.

\section{ACKNOWLEDGEMENTS}

This work was supported by the National Natural Science Foundation of China (No. 31101732), the Henan Province Programs for Science and Technology Development (No. 102102110173), the Natural Science Foundation of Henan Province (No. 2011B230011), and the Youth Foundation of Shangqiu Normal University (No. 2009QN11).

\section{REFERENCES}

Allen, C. D., D. L. Fletcher, J. K. Northcutt and S. M. Russell. 1998. The relationship of broiler breast color to meat quality and shelf-life. Poult. Sci. 77:361-366.

Biehl, R. R. and D. H. Baker. 1997a. 1 $\alpha$-Hydroxycholecalciferol does not increase the specific activity of intestinal phytase but does improve phosphorus utilization in both cecectomized and 
sham-operated chicks fed cholecalciferol adequate diets. J. Nutr. 127:2054-2059.

Biehl, R. R. and D. H. Baker. 1997b. Utilization of phytate and nonphytate phosphorus in chicks as affected by source and amount of vitamin $D_{3}$. J. Anim. Sci. 75:2986-2993.

Castellini, C., C. Mugnai and D. A. Bosco. 2002. Effect of organic production system on broiler carcass and meat quality. Meat Sci. 60:219-225.

Driver, J. P., G. M. Pesti, R. I. Bakalli and H. M. Edwards, Jr. 2005. Phytase and $1 \alpha$-hydroxycholecalciferol supplementation of broiler chickens during the starting and growing/finishing phases. Poult. Sci. 84:1616-1628.

Edelstein, S., D. Noff, D. Freeman, M. Sheves and Y. Mazur. 1978. Synthesis of 1 alpha-hydroxy $\left[7-{ }^{3} \mathrm{H}\right]$ cholecalciferol and its metabolism in the chick. Biochem. J. 176:111-117.

Edwards, H. M. Jr. 2002. Studies on the efficacy of cholecalciferol and derivatives for stimulating phytate utilization in broilers Poult. Sci. 81:1026-1031.

Fassbinder-Orth, C. A. and W. H. Karasov. 2006. Effects of feed restriction and realimentation on digestive and immune function in the leghorn chick. Poult. Sci. 85:1449-1456.

Fletcher, D. L. 1999. Broiler breast meat color variation, pH, and texture. Poult. Sci. 78:1323-1327.

Fletcher, D. L., M. Qiao and D. P. Smith. 2000. The relationship of raw broiler breast meat color and $\mathrm{pH}$ to cooked meat color and pH. Poult. Sci. 79:784-788.

Hall, L. E., R. B. Shirley, R. I. Bakalli, S. E. Aggrey, G. M. Pesti and H. M. Edwards Jr. 2003. Power of two methods for the estimation of bone ash of broilers. Poult. Sci. 82:414-418.

Han, J. C., X. D. Yang, T. Zhang, H. Li, W. L. Li, Z. Y. Zhang and J. H. Yao. 2009. Effects of $1 \alpha$-hydroxycholecalciferol on growth performance, parameters of tibia and plasma, meat quality, and type IIb sodium phosphate cotransporter gene expression of one- to twenty-one-day-old broilers. Poult. Sci. 88:323-329.

Han, J. C., Y. Liu, J. H. Yao, J. Q. Wang, H. X. Qu, Y. F. Yan, J. Yue, J. L. Ding, Z. T. Shi and X. S. Dong. 2012. Dietary calcium levels reduce the efficacy of one alphahydroxycholecalciferol in phosphorus-deficient diets of broilers. J. Poult. Sci. doi:10.2141/ jpsa.011069.
Jendral, M. J., D. R. Korver, J. S. Church and J. J. R. Feddes. 2008 Bone mineral density and breaking strength of white leghorns housed in conventional, modified, and commercially available colony battery cages. Poult. Sci. 87:828-837.

Peebles, E. D., S. W. Park, S. L. Branton, P. D. Gerard and S. k. Womack. 2011. Dietary poultry fat, phytase, and 25hydroxycholecalciferol influence the digestive and reproductive organ characteristics of commercial layers inoculated before or at the onset of lay with F-strain Mycoplasma gallisepticum. Poult. Sci. 90:797-803.

Petracci, M. and D. L. Fletcher. 2002. Broiler skin and meat color changes during storage. Poult. Sci. 81:1589-1597.

Qiao, M., D. L. Fletcher, D. P. Smith and J. K. Northcutt. 2002. Effects of raw broiler breast meat color variation on marination and cooked meat quality. Poult. Sci. 81:276-280.

Sampson, H. W. and E. L. Krawitt. 1976. A morphometric investigation of the duodenal mucosa of normal, vitamin Ddeficient, and vitamin D-replete rats. Calcif. Tiss. Res. 21:213218

SAS Institute. 2001. SAS user's guide. Version 8 ed. SAS Inst. Inc., Cary, NC. USA.

Snow, J. L., D. H. Baker and C. M. Parsons. 2004. Phytase, citric acid, and $1 \alpha$-hydroxycholecalciferol improve phytate phosphorus utilization in chicks fed a corn-soybean meal diet. Poult. Sci. 83:1187-1192.

Urban, E. and H. P. Schedl. 1969. Mucosal growth effect of vitamin D on the duodenum. Experientia 25:1270-1271.

Wang, J. X. and K. M. Peng. 2008. Developmental morphology of the small intestine of African Ostrich Chicks. Poult. Sci. 87:2629-2635.

Wiegand, B. R., J. C. Sparks, D. C. Beitz, F. C. Parrish, Jr., R. L. Horst, A. H. Trenkle and R. C. Ewan. 2002. Short term feeding of vitamin $\mathrm{D}_{3}$ improves color but does not change tenderness of pork-loin chops. J. Anim. Sci. 80:2116-2121.

Wilborn, B. S., C. R. Kerth, W. F. Owsley, W. R. Jones and L. T. Frobish. 2004. Improving pork quality by feeding supranutritional concentrations of vitamin $\mathrm{D}_{3}$. J. Anim. Sci. 82:218-224.

Xu, H., L. Bai, J. F. Collins and F. K. Ghishan. 2002. Agedependent regulation of rat intestinal type IIb sodium phosphate cotransporter by $1,25-(\mathrm{OH})_{2}$ vitamin $\mathrm{D}_{3}$. Am. J. Physiol. Cell Physiol. 282:C487-C493. 